\title{
PROFIL KEMAMPUAN KONEKSI MATEMATIS SISWA SMP DALAM PEMECAHAN MASALAH KONTEKSTUAL BERDASARKAN GAYA KOGNITIF
}

\author{
Arifah Dewi Novitasari ${ }^{1}$, Titin Masfingatin ${ }^{2}$, Reza Kusuma Setyansah ${ }^{3}$ \\ Program Studi Pendidikan Matematika, Universitas PGRI Madiun. Jalan Setiabudi No. 85, Madiun \\ E-mail: arifahnovixiia3@gmail.com, Telp: 081224338391
}

\begin{abstract}
Abstrak
Kemampuan koneksi matematis merupakan salah satu komponen yang penting dalam pembelajaran matematika.Kemampuan koneksi matematis membuat siswa memiliki pandangan yang lebih luas terhadap matematika sebab terjadi di kehidupan sehari-hari, materi yang telah dipelajari dan bidang ilmu pengetahuan lainpun. Tujuan penelitian ini adalah untuk mendeskripsikan kemampuan koneksi matematis siswa SMP yang memiliki gaya kognitif field dependent dan field independent dalam pemecahan masalah kontekstual. Jenis penelitian ini adalah penelitian deskriptif dengan pendekatan kualitatif. Subjek penelitian ini terdiri dari 2 siswa, yaitu 1 siswa dengan gaya kognitif field dependent dan 1 siswa dengan gaya kognitif field independent. Teknik pengumpulan data terdiri dari tes dan wawancara.Teknik keabsahan data dilakukan dengan triangulasi teknik. Analisis data melaluireduksi, penyajian data, dan verifikasi. Hasil penelitian diperoleh bahwa profil kemampuan koneksi matematis siswa dalam pemecahan masalah kontekstual dengan gaya kognitif field dependent dan field independent mampu mengoneksikan masalah antartopik dalam matematika. Siswa dengan gaya kognitif field dependentbelum memiliki kemampuan untuk mengoneksikan materi matematika dengan ilmu selain matematika serta belum mampu mengoneksikan materi matematika dalam kehidupan sehari-hari. Sedangkan siswa dengan gaya kognitif field independent mampumengoneksikan materi matematika dengan ilmu selain matematika serta belum mampu mengoneksikan materi matematika dengan kehidupan sehari-hari.
\end{abstract}

Kata kunci: kemampuan koneksi matematis; pemecahan masalah kontekstual; gaya kognitif

\begin{abstract}
Mathematical connection ability is an important component of mathematical learning. It makes students have a wider view of mathematics because it occurs in everyday life, material that has been learned and other fields of science. The aim of this study is to describe mathematical connections ability of secondary school students who have dependent field and independentfield cognitive style on contextual problem solving. The type of this research is descriptive research with qualitative approach. The subject of this studyconsists of 2 students, namely 1 student with dependentfield cognitive style and anotherstudent with independent field cognitive style. Data collection techniques consist of tests and interviews. Data validity techniques are performed with technical triangulation. Data analysis is through reduction, data presentation, and verification. The result of the research shows that the profile of mathematical connection ability of students on contextual problem solving with cognitive style of dependent field and independentfield are able to connect the problem between topics in mathematics. Students with dependent field cognitive style do not have the ability at connecting mathematics with other science and mathematical material with everyday life. While students with independent field cognitive
\end{abstract}


style are able to connect mathematical material with non-mathematical sciences and have not been able to connect mathematical material with everyday life.

Keywords: mathematical connection ability; contextual problem solving; cognitive style.

\section{PENDAHULUAN}

Salah satu hal yang penting bagi negara berkembang seperti di Indonesia adalah pendidikan.Pendidikan merupakan fondasi utama dalam upaya mengembangkan sumber daya manusia.Bagaimana kualitas sumber daya manusia pada suatu negara sangat ditentukan oleh kualitas pendidikan di negara tersebut.Pendidikan bertujuan untuk mengemban kemampuan dan membentuk watak serta peradaban bangsa dalam rangka mencerdaskan kehidupan bangsa (UU RI No. 20 Tahun 2003). Pendidikan yang berkualitas baik akan menciptakan sumber daya manusia yang berkualitas baik pula sehingga kehidupan bangsa dan negara akan menjadi lebih baik.

Salah satu bidang studi yang memiliki peran penting dalam meningkatkan kualitas pendidikan di Indonesia adalah matematika.Hal itu dapat dilihat dari matematika sebagai bidang studi yang diajarkan pada setiap jenjang pendidikan, mulai dari tingkat dasar hingga pendidikan tinggi. Matematika sendiri terdiri dari bagian-bagian yang saling berkaitan antara satu dengan yang lain. Keterkaitan tersebut tidak hanya pada antartopik matematika, tetapi juga dengan bidang ilmu lain dan masalah pada kehidupan sehari-hari. Hal ini menunjukkan betapa pentingnya memiliki kemampuan matematika.Salah satu tujuan pembelajaran matematika pada kurikulum 2013 (Depdikbud, 2014) adalah agar siswa memahami konsep matematika, menjelaskan keterkaitan antar konsep mengaplikasikan konsep atau algoritma secara luwes, akurasi, efisien, dan tepat dalam pemecahan masalah.

Pengetahuan matematika dipelajari melalui suatu proses pembelajaran. National Council of Teachers of Mathematics (NCTM, 2000) menetapkan lima standar kemampuan matematis yang harus dimiliki oleh siswa yaitu pemecahan masalah, penalaran dan pembuktian, komunikasi, koneksi, dan representasi. Berdasarkan hal tersebut kemampuan pemecahan masalah dan koneksi matematis merupakan hal yang penting dan perlu diperhatikan dalam pembelajaran matematika.

Dalam pembelajaran matematika siswa diharapkan dapat memecahkan masalah. Pemecahan masalah merupakan proses mengkombinasikan unsur-unsur dari pengetahuan, aturan, teknik, ketrampilan, dan konsep yang telah dipelajari untuk mendapatkan solusi pada situasi yang baru (Chanifah, 2015). Siswa diberikan masalah dengan maksud untuk melatih dan mematangkan kemampuannya dalam memahami, merencanakan, melaksanakan, dan memperoleh solusi dari masalah.Salah satu masalah yang dapat diberikan kepada siswa adalah masalah yang berhubungan dengan objek atau peristiwa yang telah dikenal baik oleh siswa atau biasa disebut masalah kontekstual.Menurut Mena, Lukita dan Siswano (2016) masalah kontekstual adalah masalah yang isinya terkait dengan kehidupan sehari-hari yang ada disekitar siswa. Melalui penggunaan masalah kontekstual dalam pembelajaran matematika, dapat menunjukkan kepada siswa bahwa obyek dan situasi yang sudah dikenal siswa dalam kehidupan sehari-hari mempunyai manfaat dalam membangun konsep matematika.Konsep-konsep matematika yang abstrak dapat dipahami berdasarkan pemikiran yang dibangun dari kondisi nyata yang sudah dikenal oleh siswa.

Pemecahan masalah memiliki peran yang penting, akan tetapi masih banyak siswa yang mengalami kesulitan dalam pemecahan masalah matematika, terutama pada pemecahan masalah kontekstual. Pemecahan masalah kontekstual adalah proses menyelesaikan masalah yang berhubungan dengan objek atau peristiwa yang telah dikenal baik oleh seseorang dalam konteks dunia nyata.Berdasarkan pengalaman peneliti saat Praktik Pengalaman Lapangan (PPL), ketika dihadapkan pada soal yang berupa masalah 
kontekstual siswa mengalami kesulitan terutama dalam memahami soal, membuat model matematikanya juga pemilihan konsep yang akan digunakan untuk menyelesaikan soal tersebut.Sementara itu hasil wawancara dengan Bapak Wahyudi selaku guru kelas VIII B SMP Negeri 1 Bendo menunjukkan bahwa siswa banyak memiliki hambatan dalam pemecahan masalah. Hal ini juga terlihat pada hasil pekerjaan siswa mengenail masalah SPLDV, dimana siswa belum mampu membuat model matematika berdasarkan masalah yang diberikan. Hal tersebut menunjukkan bahwa siswa belum mampu mengaitkan suatu masalah dengan konsep matematika.

Kesulitan yang dialami siswa dalam pemecahan masalah kemungkinan diakibatkan karena kurangnya pengetahuan siswa tentang keterkaitan antar konsep matematika.Kemampuan siswa mengaitkan antarkonsep tersebut disebut kemampuan koneksi matematis (Maisyarah dan Surya, 2017).Koneksi matematis juga termasuk dalam kemampuan matematis yang harus dikuasai siswa selain pemecahan masalah.Kemampuan matematis siswa sangat berkaitan dengan kemampuan koneksi matematisnya (Widarti, 2013).Kemampuan koneksi matematis yang baik memungkinkan siswa lebih mudah dalam belajar matematika, karena siswa mengetahui keterkaitan dari konsep yang sudah pernah dipelajari dengan konsep baru yang sedang dipelajari.Ketika siswa mempelajari mengkoneksikan atau menghubungkan konsep-konsep dalam matematika maka siswa belajar tentang kegunaan matematika (Siaginan,2016).Koneksi matematis membuat pandangan dan pengetahuan siswa menjadi lebih luas terhadap matematika, hal ini dikarenakan antartopik dalam matematika saling berkaitan, matematika berkaitan dengan kehidupan sehari-hari, selain itu juga berkaitan dengan ilmu pengetahuan yang lain.

Kemampuan koneksi matematis siswa dalam suatu pemecahan masalah sangat dipengaruhi dari bagaimana cara siswa tersebut berpikir. Setiap siswa memiliki cara sendiri dalam menyusun pikiran, apa yang dilakukan, dilihat dan diingatnya. Siswa juga memiliki cara yang berbeda dalam mengolah informasi dan menyusunnya menjadi pengalamanpengalamannya atau bisa disebut dengan gaya kognitif (Ariawan dan Nufus, 2017). Beberapa peneliti telah melaksanakan penelitian yang berkaitan dengan kemampuan koneksi matematis. Nurfitria, Hudiono dan Nursangaji(2013) meneliti tentang kemampuan koneksi matematis siswa ditinjau dari kemampuan dasar matematika di SMPdengan hasil penelitian adalah siswa dengan kemampuan matematika tinggi memiliki kemampuan koneksi matematis yang tinggi pula.Begitupun sebaliknya, siswa dengan kemampuan matematika rendah maka siswa memiliki kemampuan koneksi rendah.Penelitian yang lain adalah tentang analisis kemampuan koneksi matematis siswa Mts An Najah Jakarta Selatan oleh Fajriani dengan hasil penelitian adalah siswa mampu mengerjakan soal pada indikator koneksi antartopik pada matematika dan paling lemah pada indikator koneksi dengan kehidupan sehari-hari. Selain itu penelitian yang berkaitan dengan kemampuan koneksi matematis adalah tentang kemampuan koneksi matematis mahasiswa dalam menyelesaikan masalah pada mata kuliah kalkulus 1 ditinjau berdasarkan gaya kognitif oleh Rezi Ariawan dan Hayatun Nufus. Hasil penelitian tersebut adalah masing-masing subyek dengan masing-masing-masing kategori gaya kognitif memeliki cara berbeda dalam menyelesaikan permasalahan sesuai dengan cara mereka berpikir. Berdasarkan beberapa penelitian yang telah dilakukan, peneliti tertarik untuk melakukan penelitian yang berkaitan dengan kemampuan koneksi matematis siswa SMP dalam pemecahan masalah kontekstual berdasarkan gaya kognitif.

Gaya kognitif merupakan gaya berfikir seseorang yang melibatkan kemampuan kognitifnya yang kaitannya dengan bagaimana individu tersebut menerima, menyimpan, mengolah dan menyajikan informasi dimana gaya tersebut akan terus melekat pada individu tersebut dengan tingkat konsistensi yang tinggi dan akan mempengaruhi perilaku dan aktivitas individu baik secara langsung maupun tidak langsung (Suryanti, 2014). 
Terdapat korelasi yang tinggi antara gaya kognitif dan kemampuan pemecahan masalah matematika (Ulya, 2015). Semakin tinggi gaya kognitif siswa, semakin tinggi pula kemampuan pemecahan masalah matematika. Begitupun dengan kemampuan koneksi matematis. Masing-masing tipe gaya kognitif dapat mencapai aspek koneksi yang berbeda (Sari, 2017). Siswa dengan gaya kognitif berbeda dimungkinkan juga memiliki kemampuan koneksi matematis yang berbeda pula dalam pemecahan masalah kontekstual.

\section{METODE}

Penelitian ini dilaksanakan di Sekolah Menengah Pertama Negeri 1 bendo, kabupaten Magetan tahun ajaran 2017/2018. Waktu penelitian dilakukan pada 20 April sampai 14 Mei 2018. Jenis penelitian ini adalah penelitian deskriptif dengan pendekatan kualitatif.Penelitian deskriptif adalah penelitian yang berusaha mendeskripsikan suatu gejala, kejadian yang terjadi sekarang (Noor, 2011). Penelitian kualitatif adalah suatu proses penelitian dan pemahaman yang berdasarkan pada metodologi yang menyelidiki suatu fenomena sosial dan masalah manusia (Noor, 2011). Melalui penelitian deskriptif peneliti berusaha mendeskripsikan peristiwa dan kejadian yang menjadi pusat perhatian tanpa memberikan perlakuan khusus terhadap peristiwa tersebut.Menurut Moleong (2013) penelitian kualitatif dapat dimanfaatkan oleh peneliti untuk meneliti sesuatu secara mendalam. Pada penelitian ini penelitian kualitatif digunakan untuk meneliti kemampuan koneksi matematis siswa SMP dalam pemecahan masalah kontekstual berdasarkan gaya kognitif. Subjek penelitian ini terdiri dari 2 siswa, yaitu 1 siswa dengan gaya kognitif field dependent dan 1 siswa dengan gaya kognitif field independent. Teknik pengumpulan data terdiri dari tes dan wawancara.Teknik keabsahan data dilakukan dengan triangulasi teknik.Analisis data melaluireduksi, penyajian data, dan verifikasi.

\section{HASIL DAN PEMBAHASAN}

Profil kemampuan koneksi matematis siswa gaya kognitif field dependent dan field independent dalam pemecahan masalah kontekstual adalah sebagai berikut:

1. Siswa yang mempunyai gaya kognitif field dependent dalam pemecahan masalah kontekstual.

a. Memahami masalah

Subjek dengan gaya kognitif field dependent ini mampu mengenali hubungan gagasan antartopik dalam matematika, mampu mengenali matematika dalam konteks-konteks ilmu selain matematika dan mampu mengenali matematika dalam kehidupan sehari-hari dengan menuliskan apa yang diketahui dan apa yang ditanyakan dengan benar.

b. Merencanakan masalah

Subjek dengan gaya kognitif field dependent mampu merencanakan masalah sesuai dengan informasi yang telah diperoleh dengan memanfaatkan gagasan antartopik dalam matematika, namun belum mampu merencanakan masalah sesuai dengan informasi yang telah diperoleh dengan belum dapat menerapkan matematika dalam konteks ilmu selain matematika dan dalam konteks kehidupan sehari-hari.

c. Melaksanakan rencana

Subjek dengan gaya kognitif field dependent mampu melaksanakan rencana berdasarkan rencana yang telah direncanakan dengan memahami hubungan gagasan dalam matematika. Namun subjekbelum mampu melaksanakan masalah berdasarkan rencana yang telah direncanakan dengan belum dapat memahami gagasan dalam matematika saling mendasari satu sama lain ilmu selain matematika dan dalam konteks kehidupan sehari-hari.

d. Memeriksa kembali

Subjek dengan gaya kognitif field dependent kurang mampu melakukan pemeriksaan kembali pada jawaban yang dikerjakan. Subjekhanya membuat 
kesimpulan pada masalah koneksi antartopik pada matematika, sedangkan pada masalah koneksi matematika dengan ilmu selain matematika dan koneksi matematika dengan kehidupan sehari-hari subjek tidak membuat kesimpulan.

2. Siswa yang mempunyai gaya kognitif field independent dalam pemecahan masalah kontekstual.

a. Memahami masalah

Subjek dengan gaya kognitif field independent mampu memahami soal yang disajikan oleh peneliti. Sehingga subjek mampu mengenali hubungan gagasan antartopik dalam matematika, mampu mengenali matematika dalam kontekskonteks ilmu selain matematika dan mampu mengenali matematika dalam kehidupan sehari-hari dengan mampu menuliskan apa yang diketahui dan apa yang ditanyakan dengan benar.

b. Merencanakan masalah

Subjek dengan gaya kognitif field independent dapat merencanakan masalah sesuai informasi yang diperoleh dari soal. Sehingga subjek mampu memanfaatkan hubungan gagasan antartopik dalam matematika, menerapkan matematika dalam konteks ilmu selain matematika, dan menerapkan dalam konteks kehidupan seharihari.

c. Melaksanakan rencana

Subjek dengan gaya kognitif field independent dapat melaksanakan rencana sesuai dengan rencana yang telah direncanakan. Sehingga subjek mampu memahami gagasan dalam matematika saling berhubungan dan mendasari satu sama lain antartopik dalam matematika, memahami bagaimana gagasan dalam matematika saling berhubungan dan mendasari satu sama lain dengan ilmu selain matematika.

d. Memeriksa kembali

Siswa dengan gaya kognitif field independent dapat melaksanakan pemeriksaan kembali pada masalah koneksi antartopik dalam matematika, koneksi matematika dengan ilmu bidang ilmu selain matematika dan koneksi matematika dengan kehidupan sehari-hari.

\section{SIMPULAN}

Berdasarkan hasil pembahasan yang telah dilakukan dalam penelitian ini maka dapat disimpulkan bahwa profil kemampuan koneksi matematis siswa dalam pemecahan masalah kontekstual berdasarkan gaya kognitif sebagai berikut:

1. Profil kemampuan koneksi matematis siswa gaya kognitif field independent dalam pemecahan masalah kontekstualadalah siswa mampu mengoneksikan antartopik dalam matematika, mengoneksikan materi matematika dengan bidang ilmu lain dan mengoneksikan matematika dalam kehidupan sehari-hari pada setiap langkah pemecahan masalah.

2. Profil kemampuan koneksi matematis siswa gaya kognitif field dependent dalam pemecahan masalah kontekstual adalah siswa mampu mengoneksikan hubungan antartopik dalam matematika dalam setiap langkah pemecahan masalah. Siswa belum mampu mengoneksikan materi matematika dengan bidang ilmudan dalam kehidupan sehari-hari. Subjek hanya mampu melaksanakan pemecahan masalah pada tahap memahami masalah.

\section{DAFTAR PUSTAKA}

Chanifah, N. (2015). Geometri Siswa SMP Berdasarkan Adversity Quotient (AQ). Jurnal APOTEMA 
TRI\%20SISWA\%20SMP\%20BERDASARKAN\%20ADVERSITY\%20QUOTIEN T\%20(AQ)

Fajriani. (2017). Analisis kemampuan koneksi matematis siswa MTs An Najah Jakarta Selatan. Universitas Islam Negeri Syarif Hidayatullah. Diambil dari https://www.google.com/url?sa=t\&rct=j\&q=\&esrc=s\&source=web\&cd=1\&cad=rja \&uact $=8 \&$ ved=2ahUKEwijj72b0sTcAhVFpo8KHQq-

AxwQFjAAegQIABAC\&url=http\%3A\%2F\%2Frepository.uinjkt.ac.id\%2Fdspace\% 2Fbitstream\%2F123456789\%2F36433\%2F1\%2FFAJRIANI\%2520-

\%2520FITK.pdf\&usg=AOvVaw3G6qtCSE2rxKBr0mbne8fS

Moleong, L. J. (2013). Metodologi Penelitian Kualitatif. Bandung: Remaja Rosdakarya.

NCTM. (2000). Principles and Standards for School Mathematics. Tersedia di www.nctm.org

RI, P. Undang-undang Sistem Pendidikan Nasional (2003).

RI, P. Peraturan Menteri Pendidikan dan Kebudayaan Republik Indonesia (2014).

Mena, A. B., Lukito, A., Yuli, T., \& Siswono, E. (2016). Literasi Matematis Siswa SMP dalam Menyelesaikan Masalah Kontekstual Ditinjau dari Adversity Quotient ( AQ ). Jurnal Matematika Kreatifinovatif, 7(2), 187-198. Diambil dari: https://www.google.com/url?sa=t\&rct=j\&q=\&esrc=s\&source=web\&cd=1\&cad=rja \&uact=8\&ved=2ahUKEwjm7seYy8TcAhWIwI8KHfQHDXwQFjAAegQIARAC\& url=https\%3A\%2F\%2Fjournal.unnes.ac.id\%2Fnju\%2Findex.php\%2Fkreano\%2Farti cle\%2Fdownload\%2F6756\%2F6215\&usg=AOvVaw1duvCM9g YlhmUpDIbtHcu_

Noor, J. (2011). Metodologi Penelitian: Skripsi, Tesis, Disertasi, dan Karya Ilmiah. Jakarta: Kencana.

Nufus, H., \& Nurdin, E. (2017). Profil Kemampuan Koneksi Matematis Mahasiswa dalam Menyelesaikan Masalah Matematika Berdasarkan Level Kemampuan Akademik. Jurnal Analisa, 3(2), 115-129. Retrieved from http://journal.uinsgd.ac.id/index.php/analisa/article/view/2012/1416

Nurfitria, Bambang Hudjono, A. N. (2013). Kemampuan Koneksi Matematis Siswa Ditinjau dari Kemampuan Dasar Matematika di SMP, (1), 1-17. Diambil dari http://jurnal.untan.ac.id/index.php/jpdpb/article/view/4031

Raja Maisyarah, E. S. (2017). Kemampuan Koneksi Matematis ( Connecting Mathematics Ability ) Siswa dalam Menyelesaikan Masalah Matematika. Diambil dari: https://www.researchgate.net/publication/321803645_Kemampuan_Koneksi_Mate matis_Connecting_Mathematics_Ability_Siswa_dalam_Menyelesaikan_Masalah_ Matematika

Sari, A. S. (2017). KEMAMPUAN KONEKSI MATEMATIKA PADA MATERI TEOREMA PYTHAGORAS DITINJAU DARI GAYA KOGNITIF. Universitas Muhammadiyah Surakarta.Diambil dari: http://eprints.ums.ac.id/51242/1/NASKAH\%20PUBLIKASI.pdf

Siaginan, M. D. (2016). KEMAMPUAN KONEKSI MATEMATIK DALAM PEMBELAJARAN MATEMATIKA. Journal of Mathematics Education and Science, 2(1), 58-67.Diambil dari: https://jurnal.uisu.ac.id/index.php/mesuisu/article/view/117

Suryanti, N. (2014). Pengaruh Gaya Kognitif Terhadap Hasil Belajar Akuntansi Keuangan Menengah 1. Jurnal Ilmiah Akuntansi Dan Humanika, 4(1), 1393-1406. Diambil dari: https://ejournal.undiksha.ac.id/index.php/JJA/article/view/4601

Ulya, H. (2015). Hubungan Gaya Kognitif dengan Kemampuan Pemecahan Masalah Matematika Siswa. Jurnal Konseling GUSJIGANG, 1(2), 2011-2036.Diambil dari: http://jurnal.umk.ac.id/index.php/gusjigang/article/view/410

Widarti, A. (2012). Kemampuan Koneksi Matematis Dalam Menyelesaikan Masalah 
Kontekstual Ditinjau dari Kemampuan Matematis Siswa, 1-8.Diambil dari: https://www.academia.edu/12619786/Kemampuan_Koneksi_Matematis_Dalam_Me nyelesaikan_Masalah_Kontekstual_Ditinjau_dari_Kemampuan_Matematis_Siswa 